\title{
Pre- and Postharvest Management of Sunburn in 'Granny Smith' Apples (Malus $\times$ domestica Borkh) under Neotropical Climate Conditions
}

\author{
Vivian Severino ${ }^{1, *(\mathbb{D})}$, Mercedes Arias-Sibillotte ${ }^{1}$, Santiago Dogliotti ${ }^{1} \mathbb{D}$, Erna Frins ${ }^{2} \mathbb{D}$, José Antonio Yuri ${ }^{3}$ \\ and Jaime González-Talice ${ }^{1}$ \\ 1 Facultad de Agronomía, Universidad de la República (UDELAR), Garzón 780, \\ Montevideo CP 12900, Uruguay; marias@fagro.edu.uy (M.A.-S.); sandog@fagro.edu.uy (S.D.); \\ jgonzalez@fagro.edu.uy (J.G.-T.) \\ 2 Facultad de Ingeniería, Universidad de la República (UDELAR), Julio Herrera y Reissig 565, \\ Montevideo CP 11300, Uruguay; efrins@fing.edu.uy \\ 3 Centro de Pomáceas, Universidad de Talca, 1 Poniente 1141, Talca CP 3460000, Chile; ayuri@utalca.cl \\ * Correspondence: vseverin@fagro.edu.uy; Tel.: +598-99168635
}

check for updates

Citation: Severino, V.; Arias-Sibillotte, M.; Dogliotti, S.; Frins, E.; Yuri, J.A.; González-Talice, J. Pre- and Postharvest Management of Sunburn in 'Granny Smith' Apples (Malus $\times$ domestica Borkh) under Neotropical Climate Conditions. Agronomy 2021, 11, 1618. https:// doi.org/10.3390/agronomy11081618

Academic Editor: Santiago Signorelli

Received: 14 July 2021

Accepted: 11 August 2021

Published: 14 August 2021

Publisher's Note: MDPI stays neutral with regard to jurisdictional claims in published maps and institutional affiliations.

Copyright: (c) 2021 by the authors. Licensee MDPI, Basel, Switzerland. This article is an open access article distributed under the terms and conditions of the Creative Commons Attribution (CC BY) license (https:// creativecommons.org/licenses/by/ $4.0 /)$.

\begin{abstract}
Sun damage on apples is attributed to the occurrence of high temperatures, incident radiation, and fruit and plant water parameters, all dependent on climatic conditions and management. The development of new production areas and climate changes increase the interest in studying the behavior of the fruit under different conditions. The effect on sun damage of three nets and two chemical protectants was evaluated in a commercial orchard of 'Granny Smith' in a neotropical climate during the 2012-2016 seasons. We recorded the evolution, incidence and severity of sunburn and sunscald. Fruit surface temperature, fruit size, sprouting and return to flowering was also recorded. Incident radiation and air temperature were considered for the assessment of the crop's microclimate. The transmittance in PAR wavelength and the air temperature variation on netting treatments reached 0.4 and $9{ }^{\circ} \mathrm{C}$, respectively. The fruit surface temperature for the White-Net and Black-Net-50\% treatments was always lower than $46^{\circ} \mathrm{C}$. For the sun damaged fruits, the Black-Net$50 \%$ treatment showed the highest proportion of slightly sunburned fruits (94\%) and the lowest proportion of heavy damages, with a sunscald index equal to or less than 2 (on a scale of 1-4) in all the tested conditions. In a neotropical climate, protectant applications did not reduce the incidence of sunburn, but with the use of nets it was possible to reduce both sunburn and sunscald without affecting growth processes dependent on leaf net assimilation.
\end{abstract}

Keywords: nets; sun chemical protectants; sunscald; climate changes

\section{Introduction}

Sunburn damage originates during fruit growth and may or may not be visible at this stage. At harvest and packing, fruits showing an irregular, yellow-to-brown spot on the sunburned side are rejected. Damage without apparent symptoms at harvest and/or packing manifests itself after cold storage (sunscald) [1-3]. These colorations result from the synthesis of polyphenols and $\beta$-carotenoids in the affected portion of the skin as a potential protective mechanism against oxidative stress due to sun exposure [4-6]. Severe damage is characterized by dark-brown to black coloration due to necrosis of the epidermis and subepidermis [3]. The fruit skin's physicochemical properties in each variety, such as homogeneity, thickness and composition of the epicuticular wax, and pigment concentration, modify the refraction of incident light and determine the sensitivity to sunburn [4], being 'Granny Smith' the most sensitive cultivar [7].

High solar incident radiation and high air temperature cause photo-oxidative stress conditions and increase fruit temperature. These are considered the environmental factors that determine sunburn $[3,4,8]$. Schrader et al. [1] propose a base fruit temperature of 46 to 
$49^{\circ} \mathrm{C}$ for slight damage, and $52{ }^{\circ} \mathrm{C}$ for the occurrence of necrosis, the latter irrespective of incident radiation. Considering that the fruit temperature in the side exposed to the sun can be $18{ }^{\circ} \mathrm{C}$ higher than the air temperature and $9^{\circ} \mathrm{C}$ higher than in the unexposed side [9], the air temperature values at which fruit damage occurs should be higher than $28-32{ }^{\circ} \mathrm{C}[3]$. Although there is consensus on the predisposing environmental conditions for the occurrence of sunburn, recent works have focused on studying the role of the water status of the fruit and the tree. The location of the fruit in the canopy and its degree of acclimatization are associated with the severity of sun damage. Orchard characteristics, such as tree vigor, the presence of windbreaks and row direction, affect the incident radiation and the sensible heat of the fruit. Finally, crop water status plays a role due to its ability to cool the tissues and, therefore, reduce fruit temperature [2,10-13].

Quality losses due to sun damage have led to the development of cultivation practices to mitigate them [14], such as water spraying on foliage and fruits to lower fruit temperature [15], the use of shade nets [16], chemical formulations that reflect or filter UV radiation [17], antitranspirants [18], and canopy management [2]. Although the reduction in sunburn incidence using different types of netting, structures and cover is widely reported, the mechanisms involved are not fully described and results are highly variable depending on local climate, cultivar and management $[16,19]$. The nets reduce the total incident radiation, altering the crop's microclimate and modifying the gaseous exchange between plant and atmosphere $[20,21]$. As a result, many of the plant's physiological processes are modified, producing changes in both water use efficiency and net assimilation [22]. The effect of the netting on the crop's photosynthetic capacity depends on the total incident photosynthetically active radiation (PAR) at each location and for each time of the year. When the decrease in radiation due to the nets maintains PAR levels above the canopy PAR saturation, no problems in carbohydrate production are expected $[23,24]$. Reduced assimilation rates are associated with smaller fruit size and lower new-shoot growth [25].

The decrease in air temperature under the net, coupled with a decrease in wind speed, affects air temperature, relative humidity, and water vapor-pressure deficit. These environmental variables modify the photosynthetic efficiency, in addition to the water status of the plants and, therefore, the cooling capacity of the foliage and the fruit, thus altering the fruit's sensitivity to sun damage. The approaches linked to photosynthetic efficiency and conducted on recently harvested fruits show a decrease from 0.71 to 0 in the Fv/Fm ratio of fruit skin between 39 and $42{ }^{\circ} \mathrm{C}$. Authors who subscribe to these approaches conclude that sunscald is an expression of photo-oxidative stress in the fruit's skin, which is promoted by peel temperatures above $40^{\circ} \mathrm{C}$. Short-term field tolerance is acquired by insolation at sub-injurious temperatures, but this tolerance is rather weak and does not abide the atmospheric conditions that prevail in the Israeli summer [26]. McCaskill et al. [22] point out that reductions of up to $2{ }^{\circ} \mathrm{C}$ in fruit temperature can be obtained under nets, which reduce the intensity of the solar beam by interception and scattering while allowing sufficient air flow to enable the transfer of heat from the fruit's surface to the air. On the other hand, nets can modify the quality of incident light, affecting photomorphogenic processes and other developmental processes such as bud differentiation and the return to flowering in the following spring $[27,28]$.

Another reported management is the application of inorganic physical blockers, i.e., particles that block, reflect and scatter solar radiation [18]. These particles have been used in various crops since the 1970s with varied results. Gindaba and Wand [17] report a decrease in fruit temperature and sun damage in apple trees with the application of chemical protectants. The main drawbacks of this practice include the need for several applications to maintain constant coverage and the difficulty for the removal of the applied products at the packing lines [29].

Most of the research related to sunburn has been conducted in arid or semi-arid climates, with just a few studies performed in humid regions or addressing the differences in sensitivity to sunburn between fruits from different growing environments [30]. Research 
on crop physiology under netting has been carried out in climates with high incidence of hail, related to altitudes and/or latitudes higher than those of our experiment [31], where solar radiation is not always excessive and therefore the risk of sunburn is lower [23]. Changes in the climate of traditional growing areas increase the interest in understanding the response of temperate fruit trees to neotropical climatic conditions, such as those of our study [32].

The objective of this work is to quantify sumburn damage on apples in a neo-tropical climate and to evaluate the effect of black and white netting, as well as the application of sunburn protectants, on sprouting and growth parameters, and on sumburn damage at harvest and after cold storage.

\section{Materials and Methods}

The experiment was carried out during the 2012/2013 to 2015/2016 seasons (hereafter, seasons 1 to 4 ) in an apple orchard (Malus $\times$ domestica Borkh) of 'Granny Smith' /M7 pollinized with 'Gala', located in the department of San José, in southern Uruguay $\left(34^{\circ} 38^{\prime} 18^{\prime \prime}\right.$ S; $\left.56^{\circ} 40^{\prime} 06^{\prime \prime} \mathrm{W}, 28 \mathrm{masl}\right)$. The orchard was established in 2003 with north-south row orientation and a planting frame of $4 \mathrm{~m} \times 1.5 \mathrm{~m}$. The climate of this regional ecotone is classified by Bernardi et al. (2016) as neotropical. The soil types are mainly Argiudolls and Hapluderts and a drip irrigation system setup with a maximum daily watering capacity of $4.5 \mathrm{~mm}$.

Treatments consisted of netting and sumburn protectant (PRO) applications. Netting was evaluated throughout all 4 seasons, whereas PROs were applied in seasons 2 and 3. The nets used in all cases were monofilament nets with the following characteristics: translucent white net 20\% (WN) (only in seasons 3 and 4); black net 35\% (BN35); and black net 50\% (BN50). The PROs used were kaolin (Surround $\mathrm{WP}^{\circledR}, 50 \mathrm{~K} / \mathrm{ha}$, Tessenderlo Kerley, Inc., Phoenix, AZ, USA) and $\mathrm{CaCO}_{3}$ (Purshade ${ }^{\circledR}, 30$ 1/ha, Tessenderlo Kerley, Inc., Phoenix, AZ, USA), applied 4 and 5 times for seasons 2 and 3, respectively. All treatments were applied each season in mid-December, coinciding with weeks 6 and 9 after full bloom (WAFB), and were maintained until harvest. The flowering dates for cycles 1 to 4 were the following: 27 September (cycle 1), and 28 October, 3 and 14 (cycles 2, 3 and 4, respectively). The PRO treatments were repeated whenever necessary, depending on rainfall levels (after an accumulation of $10 \mathrm{~mm}$ ) and/or fruit cover levels.

\subsection{Experimental Design}

\subsubsection{Field Experiment}

The experimental design consisted of randomized complete blocks with 3 replicates per treatment. The net treatments covered a surface of $600 \mathrm{~m}^{2}(12 \times 50 \mathrm{~m})$, including three rows and its inter-rows, whereas PRO and Control treatments each consisted of one row of $15 \mathrm{~m}$. In all cases, measurements were made in the three central trees.

Four fruits were marked in each replicate between 40 and 50 days after full bloom (DAFB) and after fruit drop by carbohydrate balance [33-35], one in each of the following conditions: (a) exposed green fruit with no visible sun damage (GEF); (b) exposed fruit with red coloration (RF); (c) exposed fruit with incipient sunburn (SBF) or sunburn browning, according to Racsko and Schrader [18]; (d) internal green fruit with no visible sun damage (GIF) (Figure 1). Those fruits were marked at a height between 1.5 and $2 \mathrm{~m}$ in the internal and external part of the canopy.

At harvest, fruits were visually classified according to the degree of sumburn into the following categories proposed by Torres et al. [33]: HF, healthy fruit; Mild, slight discoloration on the skin or mild sunburned symptoms on less than $25 \%$ of the surface; Mod, moderate sunburned fruit with yellowing and browning on 25 to $50 \%$ of the skin surface; and Sev, severe sunburned fruit with more than $50 \%$ sunburn or dark brown patches over light browning. These categories consider both symptom type and quantification of the surface, with symptoms described by Racsko and Schrader [18] and Torres et al. [36], as 
a way of following a standard evaluation procedure to reduce the difficulties of visual grading.

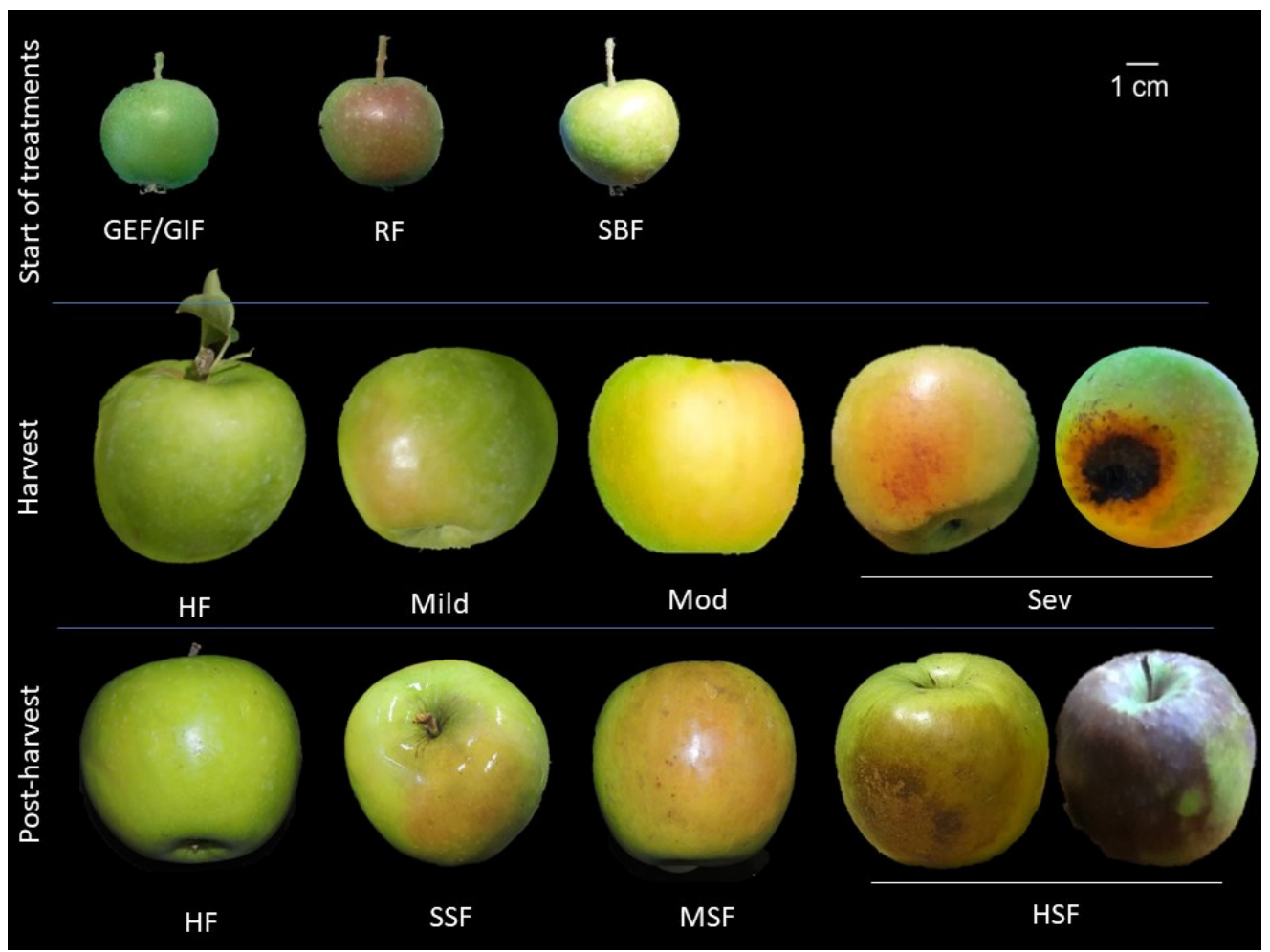

Figure 1. Examples of fruit categories at three stages of damage development. At the beginning of treatments (6 WAFB = weeks after full bloom): RF = red fruit, GEF = green external fruit, GIF = green internal fruit, and SBF = sunburned fruit. At harvest: HF = healthy fruit, Mild = slightly sunburned fruit, Mod = moderately sunburned fruit, Sev = heavily sunburned fruit; and Post-harvest: $\mathrm{HF}=$ healthy fruit, SSF = slightly sunscalded fruit, MSF = moderately sunscalded fruit, HSF = heavily sunscalded fruit.

\subsubsection{Postharvest Experiment}

Postharvest experiment was evaluated in seasons 2 and 3, using a randomized $5 \times 2 \times 2$ factorial design in each season. We applied five levels for field treatments, two levels for fruit condition at harvest (HF and Mild) and two levels for antiscaldant application to prevent superficial scald (with or without product application). The experimental unit consisted of a box with an average of 78 fruits, which was replicated 3 times. Each replicate was palletized and stored in commercial cold storage at a temperature of $0-1{ }^{\circ} \mathrm{C}$ and 95\% RH. Diphenylamine (DPA) treatment was performed in season 2 at 2000 ppm for $1 \mathrm{~min}$ at $22{ }^{\circ} \mathrm{C}$. In season $3,75 \mathrm{mg} \mathrm{m}^{-3}$ of $1-\mathrm{MCP}$ was applied in a commercial storage at room temperature.

\subsection{Evaluations}

\subsubsection{Microclimate}

The effect of the nets on the radiation affecting the crop was evaluated with an Ocean Optics spectrometer, model S2000, 1 nm resolution, which covers a wavelength range from 250 to $800 \mathrm{~nm}$. The spectra were evaluated twice in the tested period, on cloudless days and between 12:00 and 15:00 $\mathrm{h}$ (local time $=\mathrm{GMT}-3 \mathrm{~h}$ ).

During the $15 / \mathrm{JAN}-27$ /FEB period of season 4 , the air temperature (AT) of each treatment was recorded every half hour using i-button sensors located inside the canopy of the trees and protected from direct solar radiation. 
The maximum fruit surface temperature (FST) was recorded using an IR camera (FLIR E50) on three days at 12 WAFB of seasons 2 and 3, between 13:00 and 16:00 h, with maximum AT (ATmax) between 33 and $35^{\circ} \mathrm{C}$.

\subsubsection{Sunburn}

From 6 WAFB onwards, the evaluation of sun damage was recorded weekly by visual determination on the marked fruits.

At harvest, the fruits from each treatment were manually sorted into the four abovementioned categories: HF, Mild, Mod and Sev (Figure 1). Fruits classified as HF and Mild were retained for postharvest evaluation.

\subsubsection{Fruit Growth and Sprouting}

From 6 WAFB onwards, fruit size development was measured weekly on a random sample of 15 fruits per tree. After harvest, we counted the number of shoots and spurs on one branch per tree and measured the length of the shoots. In the blooms corresponding to seasons 2, 3 and 4 for each treatment, we evaluated the return to flowering on the same branch.

\subsubsection{Post-Harvest}

The incidence and severity of scald was evaluated three times during each conservation season. In season 2, evaluations were made at 60, 120 and 210 days of cold storage, while in season 3 evaluations were made at 82, 133 and 245 days. Incidence was expressed as the presence or absence of alterations, and severity was classified on a 4-point scale, in which 1 corresponds to healthy fruits (HF), 2 to slightly scalded fruits (SSF, 25\% of the fruit's surface), 3 to moderately scalded fruits (MSF, 25-50\% of the surface), and 4 to heavily scalded fruits (HSF, greater than 50\%) (Figure 1).

\subsection{Statistical Analysis}

Statistical analyses were performed using the R statistical software. The interpretation of binary data $(0 / 1)$ was performed with generalized linear models (GLM) and binomial distribution. For continuous variables, normality and homogeneity of variances were tested prior to the analysis using Shapiro and Levene tests, respectively $(p>0.05)$. An analysis of variance (ANOVA) was performed when the assumptions of normality and homogeneity of variances were met, and a non-parametric Kruskal-Wallis test was applied when the ANOVA was not appropriate. The analysis of ordinal variables such as the level of sunburn or scald was performed with a Cumulative Link Model (CLM) and a Type II ANOVA test to establish the significance of the model effects. When required, Tukey or Mann-Whitney-Wilcoxon tests $(p<0.05)$ were performed.

\section{Results}

\subsection{Changes in Microclimate \\ Incident Radiation and Air and Fruit Temperature}

The nets mainly modified the maximum temperatures depending on their color. Daily ATmax showed the greatest differences among treatments, reaching a $9{ }^{\circ} \mathrm{C}$ maximum variation in the studied period. The Control treatment presented an ATmax of $43{ }^{\circ} \mathrm{C}$, while the $\mathrm{WN}$ treatment reached $47^{\circ} \mathrm{C}$ in the evaluated period. The lowest ATmax values were recorded in black net treatments: $39^{\circ} \mathrm{C}$ and $38^{\circ} \mathrm{C}$ for BN50 and BN35, respectively (Figure 2). Daily ATmed ranged from $23^{\circ} \mathrm{C}$ to $25^{\circ} \mathrm{C}$, and ATmin from $9^{\circ} \mathrm{C}$ to $10^{\circ} \mathrm{C}$ (data not shown). 


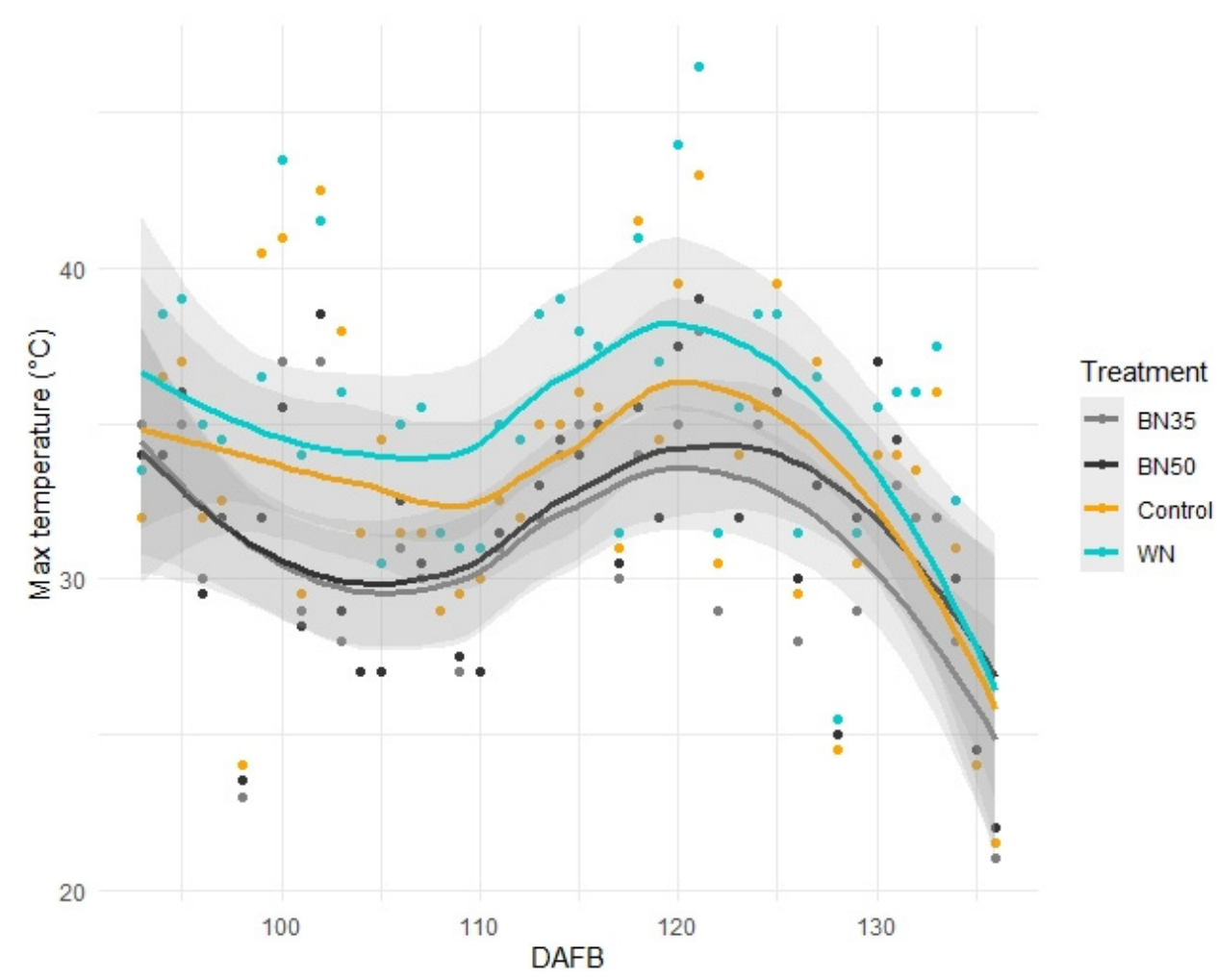

Figure 2. Evaluation of the maximum air temperature in the treatments under netting $(\mathrm{BN} 35=\mathrm{Black}$ net 35, BN50 = Black net 50, WN = White net) and the Control treatment. DAFB = days after full bloom in season 4 . Dots represent the maximum daily temperature. Lines and 0.95 confidence intervals were calculated according to the geom_smooth function (loess method in R).

FST showed differences in relation to treatment and fruit type (SBF, RF, GEF, GIF) (Figures 3 and 4). The highest FST were recorded in the PRO and Control treatments, with 35 and $43 \%$ of measurements above $46{ }^{\circ} \mathrm{C}$, respectively. BN35 had $14 \%$ of the FST measurements above $46^{\circ} \mathrm{C}$, while $\mathrm{WN}$ and BN50 did not present temperatures above this threshold. SBF showed the highest dispersion, with a mean FST of $43{ }^{\circ} \mathrm{C}$, higher than $\mathrm{RF}$ and GIF $\left(41^{\circ} \mathrm{C}\right)$ (Figure 3). The distribution of the intrafruit surface varied among treatments (data not shown). The standard deviation of temperature values was 3.1 for the Control treatment to 1.9 for BN50, an example of which is shown in Figure 4.

The transmittance of BN50 and WN in the PAR wavelength range was $0.40( \pm 0.03)$ and $0.70( \pm 0.03)$, respectively. In the near IR (between 700 and $800 \mathrm{~nm}$ ), the behavior of both materials varied. The transmittance of $\mathrm{WN}$ increased to values close to $100 \%$, whereas in the case of BN50 the transmittance decreased to values of around 0.35 (Figure 5). 
a

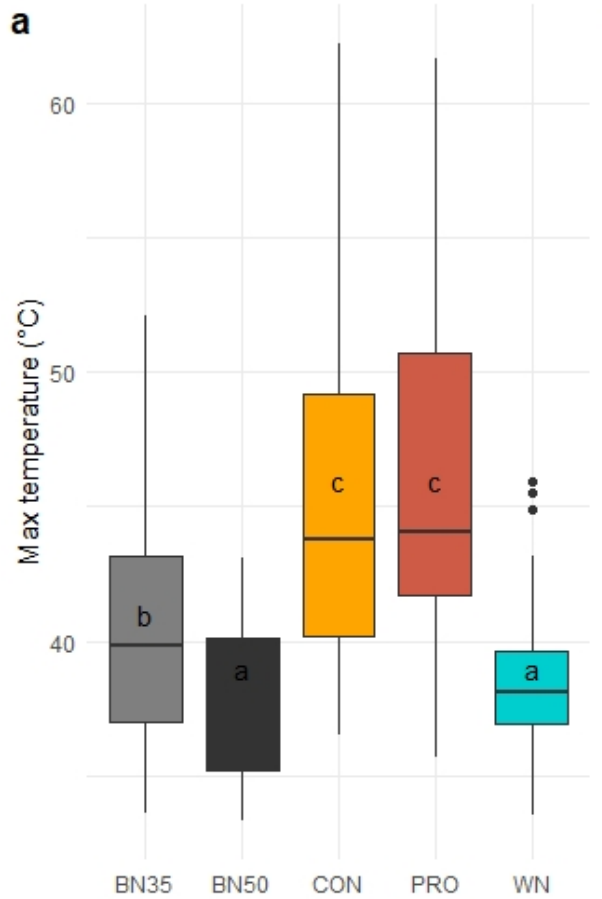

b

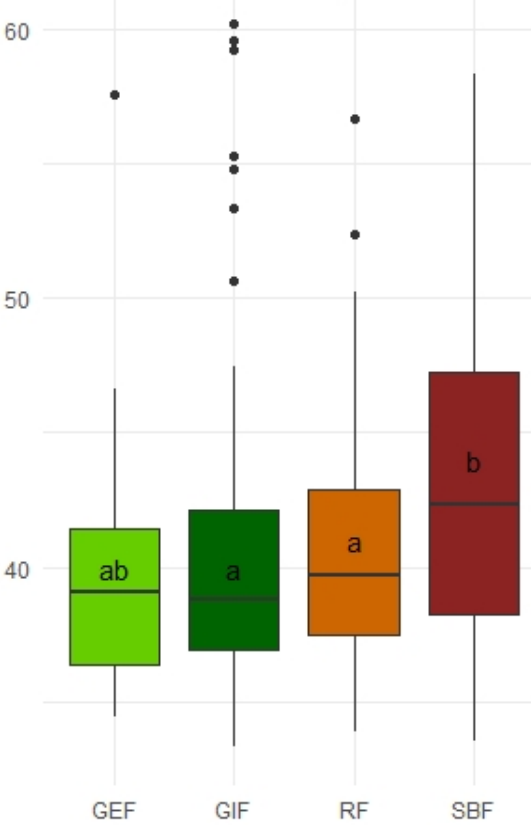

•

Figure 3. Maximum fruit surface temperature (FST) according to: (a). treatment (BN35 = Black net 35, $\mathrm{BN} 50=$ Black net $50, \mathrm{WN}=$ White net, $\mathrm{CON}=$ control and $\mathrm{PRO}=$ protectants), and (b). fruit condition $(\mathrm{RF}=$ red fruit, GEF = green external fruit, GIF = green internal fruit, and SBF = sunburned fruit). The box represents interquartile range (IQR); the upper $(\mathrm{Q} 3)$ and lower $(\mathrm{Q} 1)$ quartiles are the ends. The line in the box is the median and the whiskers are the range of the data, excluding outliers. Outliers are values higher than Q3 + 1.5 IQR or smaller than Q1 - 1.5 IQR. Boxes with different letters indicate significant differences $(\alpha=0.05)$.

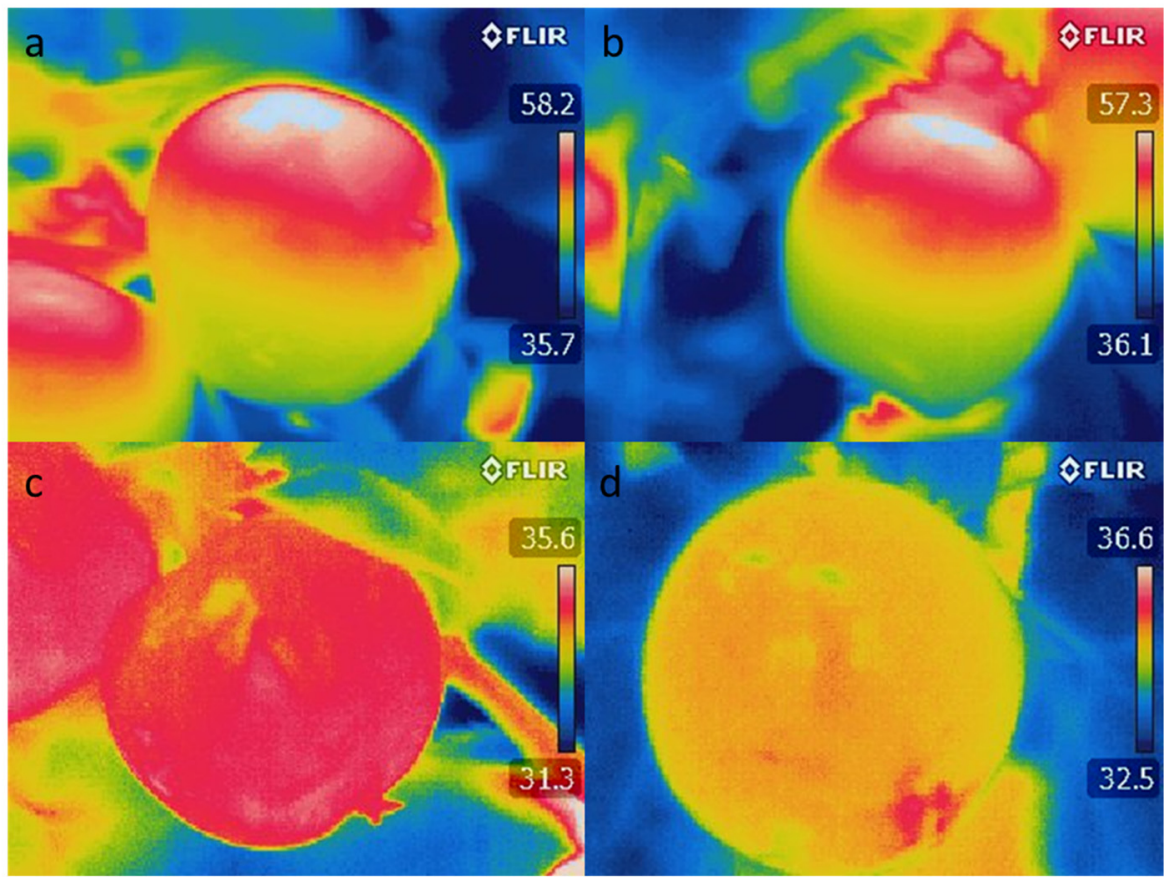

Figure 4. Examples of fruit temperature evaluated with an IR camera (FLIR E50). The scale represents the temperature $\left({ }^{\circ} \mathrm{C}\right)$ in each image. $(\mathbf{a}, \mathbf{b})$ are fruits in the Control treatment $(\mathrm{CON})$, while $(\mathbf{c}, \mathbf{d})$ are fruits in BN50 (Black net 50\%). 


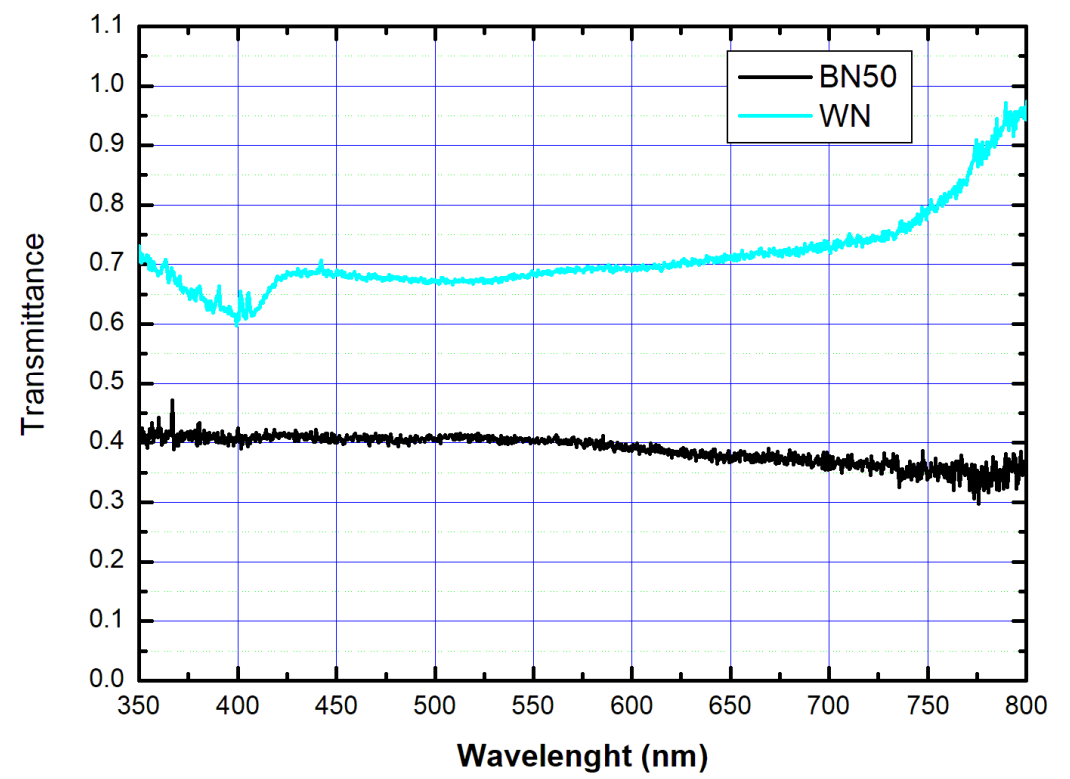

Figure 5. Transmitted radiation proportion between 350 to $800 \mathrm{~nm}$ for BN50 and WN treatments (Black Net $50 \%$ and White Net, respectively).

\subsection{Sunburn}

\subsubsection{Sunburn Changes during the Season}

The incidence of sunburn showed a different evolution according to the season, the initial condition of the fruit, and the protection treatment. In green internal fruits, the percentage of sunburn did not exceed $20 \%$, while in sunburned fruits the final sunburn percentages ranged between 50 and 100\% under all treatments in seasons 2 and 3 and under non-mesh treatments in seasons 1 and 4 . Under netting treatments, the incidence of sunburn decreased drastically in seasons 1 and 4 in the first weeks of measurement and remained at low values as the season progressed. In green external fruits and red fruits, progressive increases were recorded during the evaluation period, with variations in the evolution between treatments and seasons. For red fruit, the maximum values of sunburn under netting (BN35, BN50, WN) were $75 \%$. Values close to $100 \%$ were recorded for the $\mathrm{PRO}$ and Control treatments in season 2. For green external fruits, sunburn damage also increased as the season progressed, with results similar to those recorded for red fruits (Figure 6).

The incidence of final sunburn on marked fruits was significant for all the analyzed sources of variation (Figure 7). In the analysis according to season, seasons 2 and 3 showed the highest percentages of sunburned fruits, without reaching statistical differences with season 1 but doing so with season 4 (Figure 7a). In the analysis according to fruit type, Green internal fruits showed a median equal to $0 \%$ and lower than all other fruit types. Sunburned fruits and red fruits showed final sunburn values higher than $60 \%$ ( 65 and $62 \%$, respectively) that did not differ statistically from those of green external fruits (Figure $7 \mathrm{~b}$ ). The treatments with the highest values of sunburned fruits were PRO and Control (64 and $50 \%$, respectively), although pairwise comparisons did not reach significant differences (Figure 7c). 


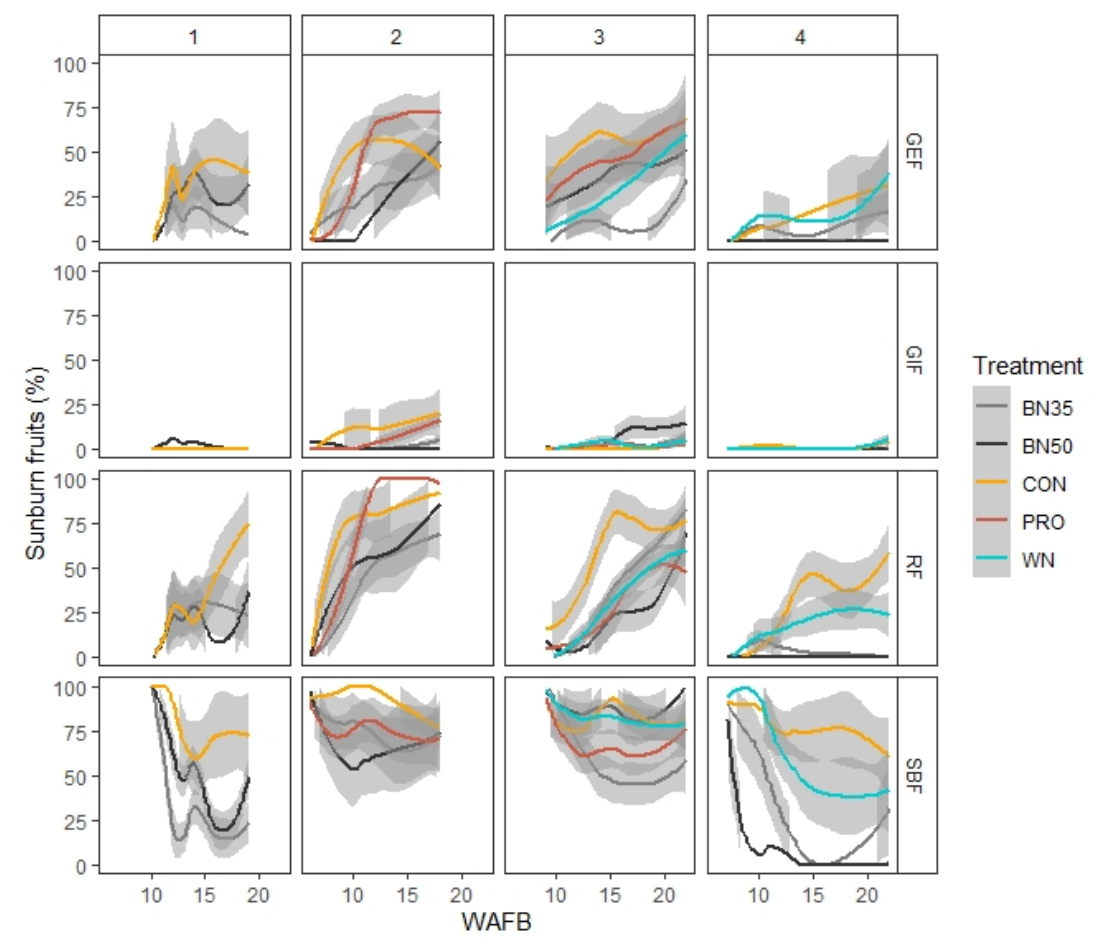

Figure 6. Evolution of the percentage of sunburned fruits by treatment (BN35 = Black net 35, $\mathrm{BN} 50=$ Black net $50, \mathrm{WN}=$ White net, $\mathrm{CON}=$ control and $\mathrm{PRO}=$ protectants) according to weeks after full bloom (WAFB), fruit condition (RF = red fruit, GEF = green external fruit, GIF = green internal fruit, and SBF = sunburned fruit) and season (1 to 4). Lines and 0.95 confidence intervals were calculated according to geom_smooth function (loess method in R).
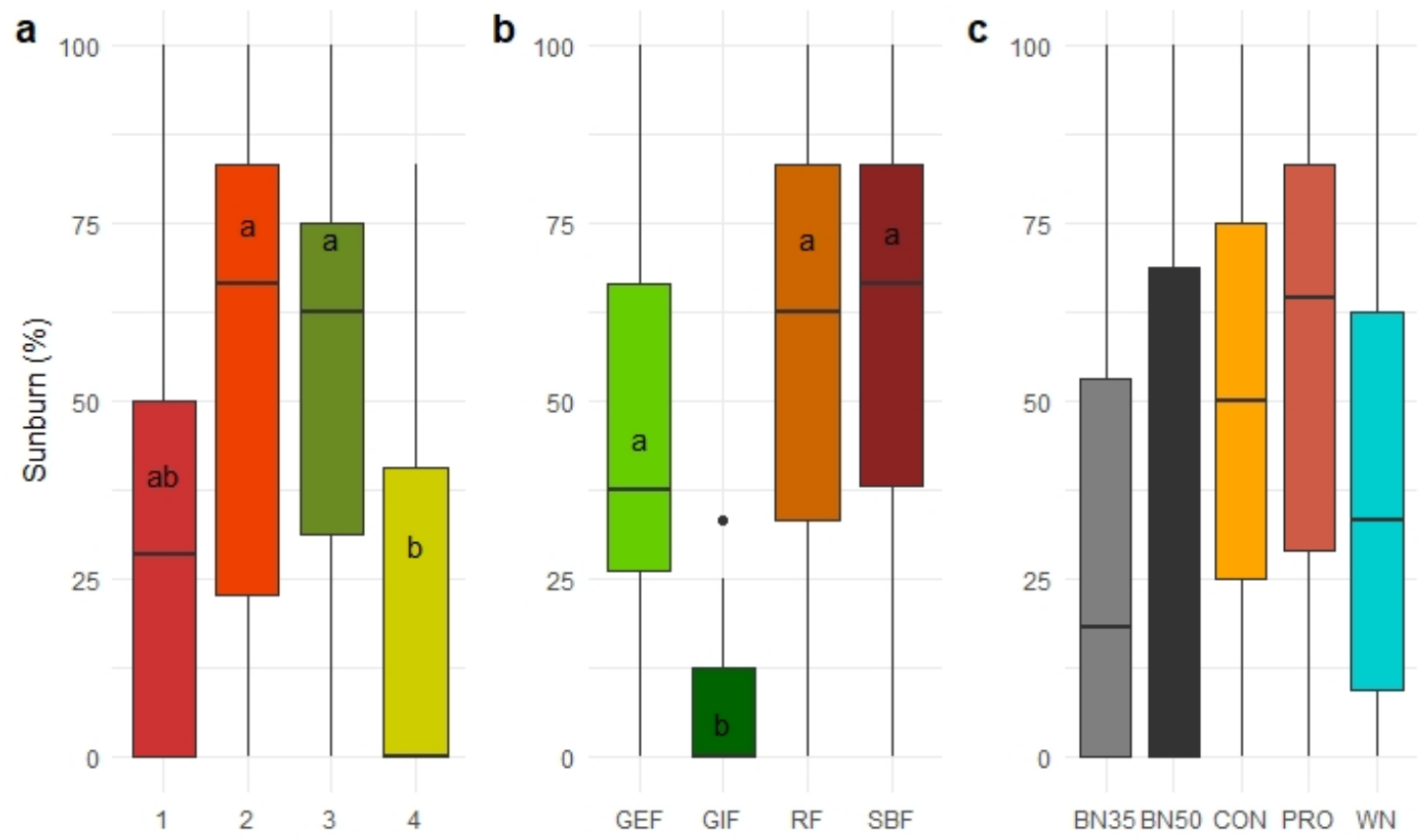

Figure 7. Incidence of final sunburn in evaluated fruits, according to: (a). season (1 to 4), (b). fruit condition (RF = red fruit, $\mathrm{GEF}=$ green external fruit, GIF = green internal fruit, and SBF = sunburned fruit), and (c). treatment (BN35= Black net 35 , $\mathrm{BN} 50=$ Black net $50, \mathrm{WN}=$ White net, $\mathrm{CON}=$ control and $\mathrm{PRO}=$ protectants). The box represents interquartile range (IQR); the upper $(\mathrm{Q} 3)$ and lower $(\mathrm{Q} 1)$ quartiles are the ends. The line in the box is the median and the whiskers are the range of the data, excluding outliers. Outliers are values higher than Q3 + 1.5 IQR or smaller than Q1 - 1.5 IQR. Boxes with different letters indicate significant differences $(\alpha=0.05)$; the absence of letters indicate non-significant differences. 


\subsubsection{Sunburn at Harvest}

The percentage of sunburned fruits out of the total harvested fruits showed differences between treatments, seasons, and their interaction (Figure 8a). The distribution between sunburn levels was significant only within treatments. The BN50 treatment showed the highest proportion of Mild and the lowest proportion of Mod + Sev, whereas PRO showed the highest proportion of Sev (Figure 8b).
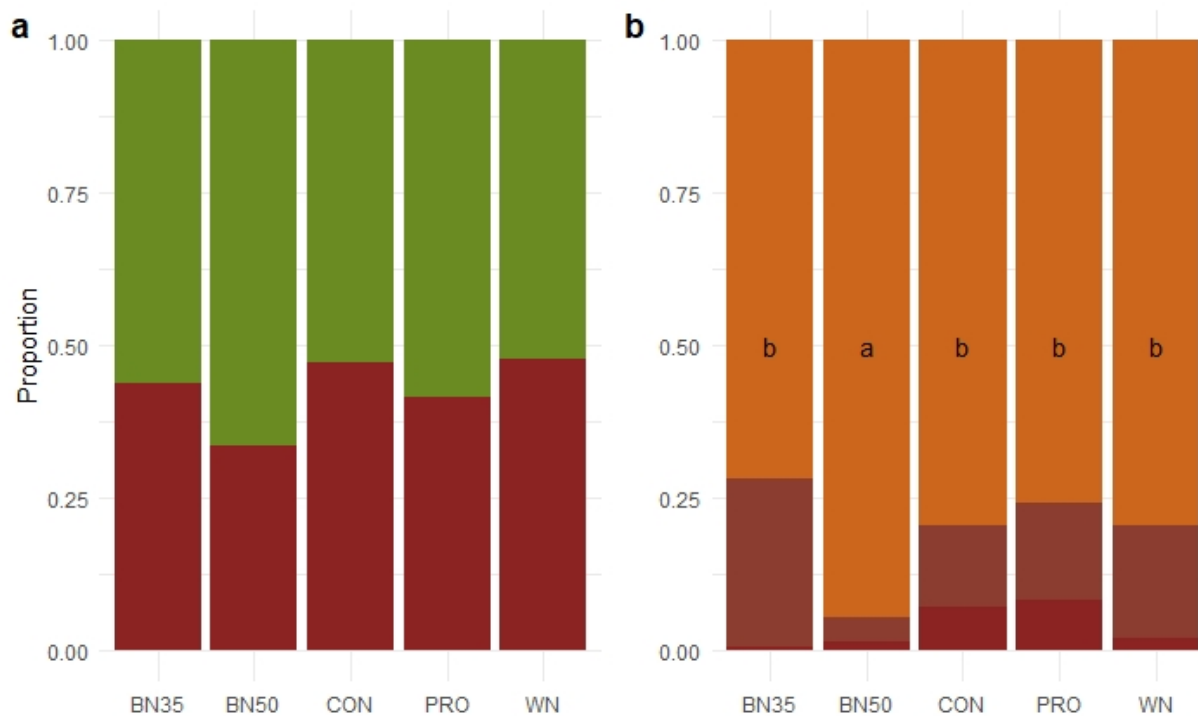

Figure 8. (a). Incidence of sunburn at harvest according to treatment (BN35 = Black net 35, $\mathrm{BN} 50=$ Black net $50, \mathrm{WN}=$ White net, $\mathrm{CON}=$ control and $\mathrm{PRO}=$ protectants $) \mathrm{SBF}=$ sunburned fruit (brown) $\mathrm{HF}=$ healthy fruit (green); (b). severity of sunburn at harvest according to treatment (BN35 = Black net 35, BN50 = Black net 50, $\mathrm{WN}=$ White net, $\mathrm{CON}=$ control and $\mathrm{PRO}=$ protectants), the intensity of the color brown represents the intensity of the sunburn: Mild = slightly sunburned fruit (orange), Mod = moderately sunburned fruit (light brown), Sev = heavily sunburned fruit (brown). Bars with different letters indicate significant differences $(\alpha=0.05)$, absence of letters indicate non-significant differences.

\subsection{Fruit Growth and Sprouting}

The effect of the treatments on final fruit size depended on the seasons. The largest difference found between the largest and smallest fruits was very small, being $2.5 \mathrm{~mm}$ in Control and WN fruits in season 4 (Table 1). The mean final fruit diameter was 61, 71, 68 and $66 \mathrm{~mm}$ for seasons 1 to 4 , respectively (data not shown).

Table 1. Fruit size difference between smallest and largest size at harvest by season and treatment (BN35 = Black net 35, BN50 = Black net 50, WN = White net, $\mathrm{CON}=$ control and PRO = protectants).

\begin{tabular}{ccccc}
\hline & \multicolumn{3}{c}{ Size of Last Date Evaluated before Harvest } \\
\cline { 2 - 5 } & $\begin{array}{c}\text { Largest Size } \\
\text { Treatment }\end{array}$ & $\begin{array}{c}\text { Smallest Size } \\
\text { Treatment }\end{array}$ & $\begin{array}{c}\text { Maximum } \\
\text { Difference }\end{array}$ \\
\hline Season 1 & BN35 & CON & $1.4 \mathrm{~mm}$ & $*$ \\
Season 2 & PRO & MN50 & $1.0 \mathrm{~mm}$ & $\mathrm{Ns}$ \\
Season 3 & WN & BN50 & $1.5 \mathrm{~mm}$ & Ns \\
Season 4 & CON & WN & $2.5 \mathrm{~mm}$ & $*$ \\
* Indicates significant difference $(\alpha=0.05)$ between indicated treatments in the row, ns = not significant.
\end{tabular}

${ }^{*}$ Indicates significant difference $(\alpha=0.05)$ between indicated treatments in the row, $\mathrm{ns}=$ not significant. 
The seasons showed differences for all sprouting variables (length of shoots, percentage of reproductive shoots and percentage of spurs). The treatment effect was only significant for the length of shoots variable, whereas the interaction was not significant (Table 2). The range of variation for the percentage of reproductive shoots was between 24 and $77 \%$ in seasons 2 and 3, respectively. The growth of shoots in seasons 2 and 3 (15 and $17 \mathrm{~cm}$, respectively) was $30 \%$ lower than in season 1 . Average sprouting percentages of 48 and $57 \%$ were recorded for spurs and reproductive shoots, respectively, for all treatments.

Table 2. Effect of season (1, 2 and 3$)$ and treatments $(B N 35=$ Black net $35, B N 50=$ Black net $50, \mathrm{WN}=$ White net and $\mathrm{CON}=$ control) on shoot length, percentage of reproductive structures (\%reproductive), and percentage of short internode structures (\%spurs) at next sprouting.

\begin{tabular}{|c|c|c|c|c|c|c|}
\hline & \multicolumn{2}{|c|}{ Shoot Length } & \multicolumn{2}{|c|}{ \%Reproductive * } & \multicolumn{2}{|c|}{$\%$ Spurs * } \\
\hline 1 & 22.30 & a & 61.99 & $\mathrm{~b}$ & 35.02 & $\mathrm{~b}$ \\
\hline 2 & 15.21 & $b$ & 24.36 & c & 55.31 & $\mathrm{a}$ \\
\hline 3 & 16.89 & $\mathrm{~b}$ & 77.62 & a & 49.79 & a \\
\hline \multicolumn{7}{|c|}{ Treatment } \\
\hline WN & 17.65 & $b$ & 55.75 & & 50.35 & \\
\hline BN35 & 15.14 & c & 59.05 & & 44.64 & \\
\hline BN50 & 22.01 & $\mathrm{a}$ & 65.56 & & 49.29 & \\
\hline $\mathrm{CON}$ & 19.11 & a & 48.76 & & 45.98 & \\
\hline
\end{tabular}

* Evaluated the following spring. Different letters next to values in each group indicate significant differences $(\alpha=0.05)$.

\subsection{Postharvest Evaluation}

\subsubsection{Scald Damage}

Since the antiscaldant treatment varied for seasons 2 and 3 (DPA and 1-MCP, respectively), the results of the postharvest evaluation were analyzed independently (Figures 9 and 10). In both seasons, the model was significant for field treatments (Control, PRO, BN35, BN50, and $\mathrm{WN}$ ), fruit condition when entering cold storage (HF and Mild), storage time and postharvest treatment, as well as their interactions. Successive evaluations of all conditions recorded an increase in damage, both in incidence and severity. Fruits without evidence of sunburn (HF) before cold storage had higher proportions of fruits without scald (HF) during storage. Both antiscaldants had similar effects by increasing the proportion of HF and reducing moderate and heavily scalded fruits (MSF and HSF) (Figures 9 and 10). 

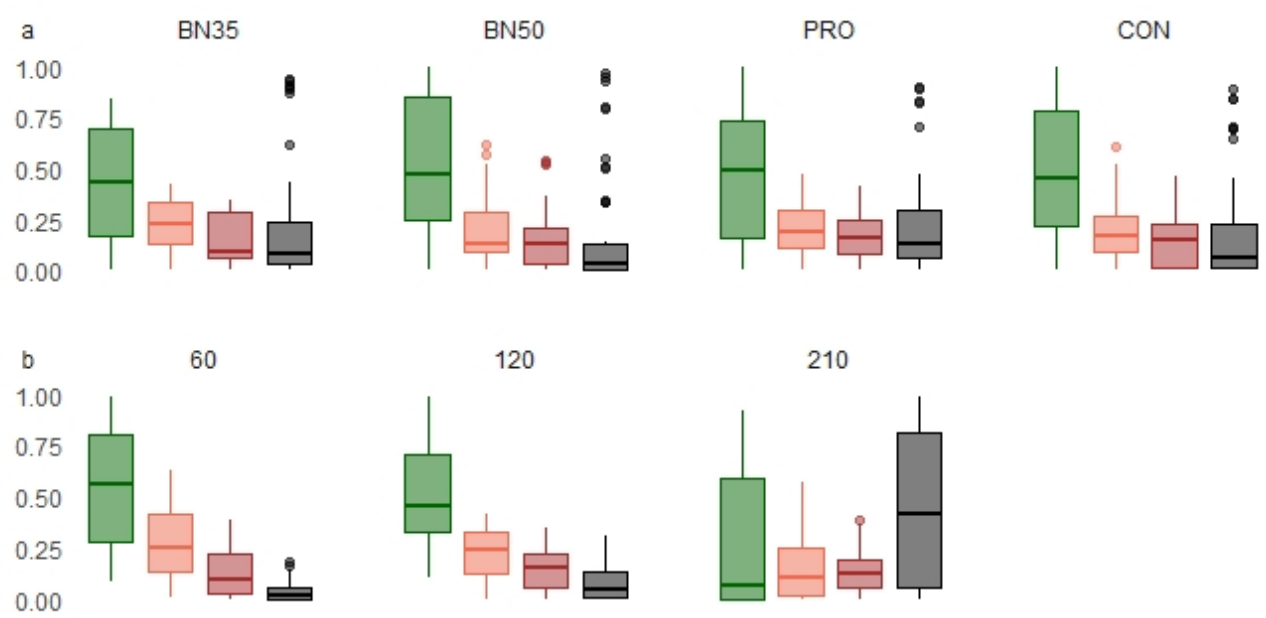

210
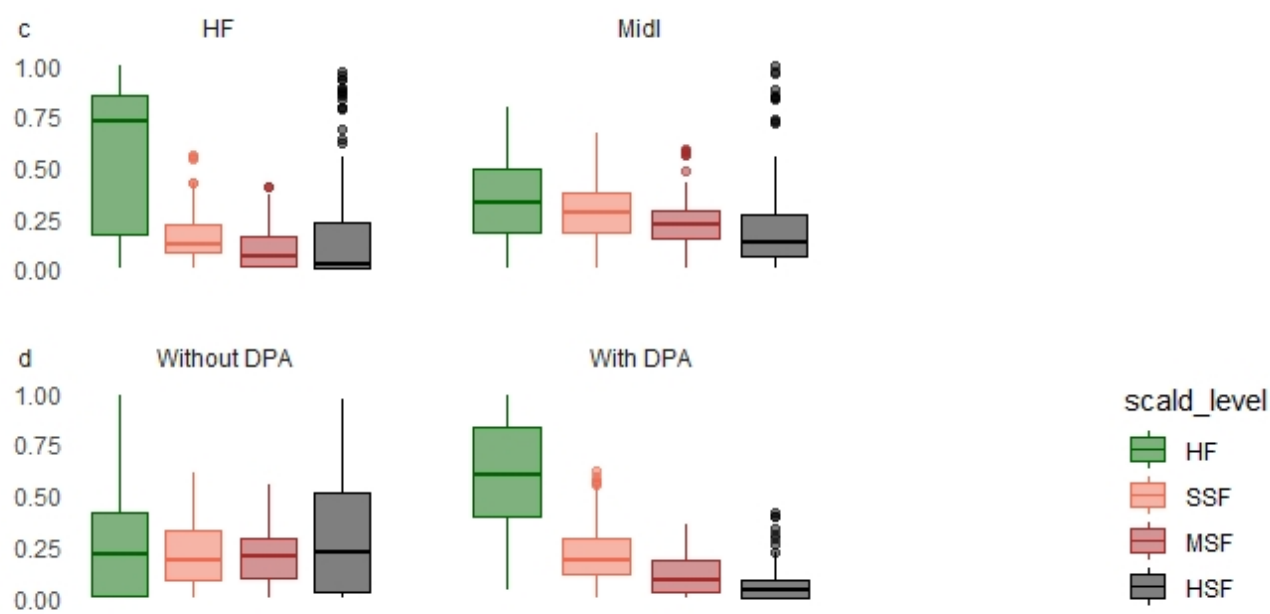

Figure 9. Proportion of fruits at each level of scald (HF healthy fruit, SSF = slightly scalded fruit, MSF = moderately scalded fruit, HSF = heavily scalded fruit) for season 2, according to: (a). field treatment (BN35 = Black net 35, BN50 = Black net 50, CON = control and PRO = protectants), (b). days of storage, (c). sun damage at harvest (HF, healthy fruit; Mild, light sunburn), and (d). post-harvest treatment (without DPA or with DPA). The box represents interquartile range (IQR); the upper (Q3) and lower (Q1) quartiles are the ends. The line in the box is the median and the whiskers are the range of the data, excluding outliers. Outliers are values higher than Q3 + 1.5 IQR or smaller than Q1 - 1.5 IQR. 


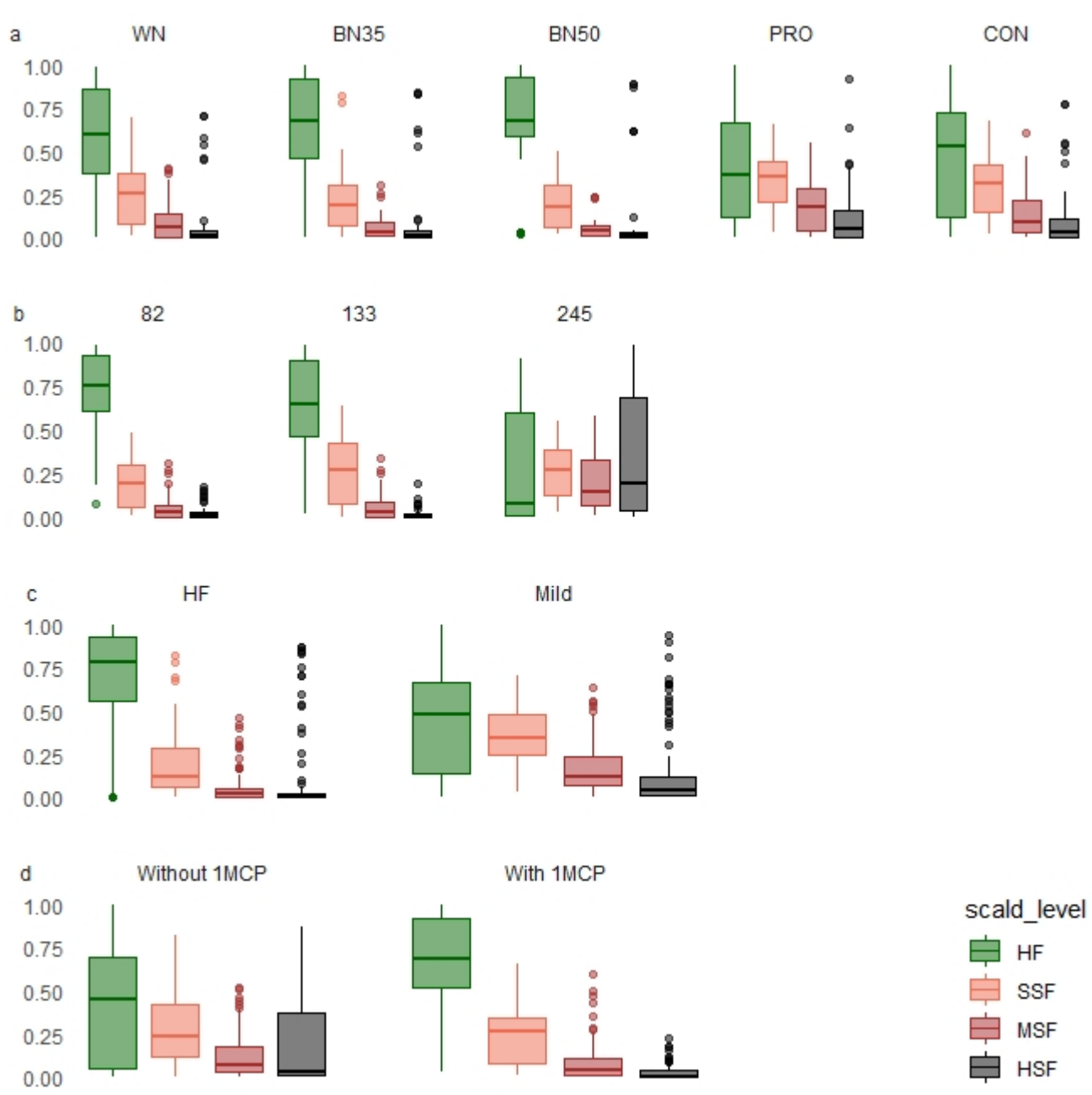

Figure 10. Proportion of fruits at each level of scald (HF healthy fruit, SSF = slightly scalded fruit, MSF = moderately scalded fruit, HSF = heavily scalded fruit) for season 3, according to: (a). field treatment $(\mathrm{BN} 35=$ Black net $35, \mathrm{BN} 50=$ Black net 50, $\mathrm{WN}=$ White net, $\mathrm{CON}=$ control and $\mathrm{PRO}=$ protectants), (b). days of storage, (c). sun damage at harvest (HF healthy fruit, SIS light sunburn), and (d). post-harvest treatment (without 1-MCP or with 1-MCP). The box represents interquartile range (IQR); the upper $(\mathrm{Q} 3)$ and lower $(\mathrm{Q} 1)$ quartiles are the ends. The line in the box is the median and the whiskers are the rang of the data, excluding outliers. Outliers are values higher than Q3 + 1.5 IQR or smaller than Q1 - 1.5 IQR.

\subsubsection{Sunscald Damage}

An analysis of the interaction between field treatment and sunburn level on the evolution of scald was carried out on fruits treated with antiscaldants. In both seasons, HF had lower scald values than Mild, considering both the proportion of damaged fruits and the index of scalding. BN50 had the lowest scald values in 55\% of the generated conditions, defined by evaluation method, season, fruit condition and field treatment. PRO had the lowest values in $66 \%$ of the conditions in both seasons (Table 3 ). 
Table 3. Sunscald index ( 1 to 4 ) and proportion of sunscald according to season, sun damage condition at harvest $(\mathrm{HF}=$ healthy fruit, Mild = slightly sunburned fruit $)$, field treatments $(B N 35=$ Black net 35, BN50 = Black net 50, WN = White net, $\mathrm{CON}=$ control and $\mathrm{PRO}=$ protectants), and days of storage.

\begin{tabular}{|c|c|c|c|c|c|c|c|c|c|c|c|c|c|c|}
\hline \multirow{3}{*}{ 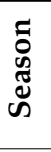 } & \multirow{3}{*}{ 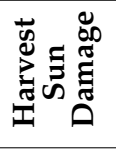 } & \multirow{3}{*}{ 莺 } & \multicolumn{7}{|c|}{ Sunscald Index } & \multicolumn{5}{|c|}{ Proportion of Sunscald } \\
\hline & & & \multicolumn{12}{|c|}{ Days of Storage } \\
\hline & & & 60 & & 120 & & 210 & & 60 & & 120 & & 210 & \\
\hline \multirow[t]{9}{*}{2} & Mild & BN35 & 1.62 & $\mathrm{~b}$ & 1.80 & $\mathrm{~b}$ & 2.16 & a & 0.37 & ns & 0.47 & ns & 0.63 & ns \\
\hline & & BN50 & 1.64 & $\mathrm{~b}$ & 2.00 & $\mathrm{~b}$ & 1.67 & $\mathrm{~b}$ & 0.41 & & 0.54 & & 0.46 & \\
\hline & & PRO & 1.90 & $\mathrm{a}$ & 2.20 & $\mathrm{a}$ & 2.22 & $\mathrm{a}$ & 0.49 & & 0.58 & & 0.57 & \\
\hline & & $\mathrm{CON}$ & 1.81 & $a b$ & 1.86 & $b$ & 1.92 & $a b$ & 0.49 & & 0.50 & & 0.55 & \\
\hline & $\mathrm{HF}$ & BN35 & 1.37 & ns & 1.39 & $\mathrm{a}$ & 1.40 & ns & 0.28 & $\mathrm{a}$ & 0.29 & a & 0.26 & ns \\
\hline & & BN50 & 1.00 & & 1.17 & bc & 1.20 & & 0.00 & $\mathrm{~d}$ & 0.14 & $\mathrm{~b}$ & 0.14 & \\
\hline & & PRO & 1.30 & & 1.30 & $a b$ & 1.30 & & 0.17 & $\mathrm{~b}$ & 0.15 & $\mathrm{~b}$ & 0.19 & \\
\hline & & $\mathrm{CON}$ & 1.14 & & 1.10 & c & 1.30 & & 0.10 & c & 0.06 & c & 0.20 & \\
\hline & & & 82 & & 133 & & 245 & & 82 & & 133 & & 245 & \\
\hline \multirow[t]{10}{*}{3} & Mild & WN & 1.47 & b & 1.74 & $\mathrm{~b}$ & 1.79 & c & 0.36 & $\mathrm{~b}$ & 0.54 & c & 0.55 & c \\
\hline & & BN35 & 1.22 & c & 1.16 & d & 1.48 & $\mathrm{~d}$ & 0.17 & c & 0.16 & e & 0.40 & d \\
\hline & & BN50 & 1.48 & $\mathrm{~b}$ & 1.48 & c & 1.63 & $\mathrm{~cd}$ & 0.39 & $\mathrm{~b}$ & 0.41 & $\mathrm{~d}$ & 0.46 & d \\
\hline & & PRO & 1.93 & a & 2.26 & a & 2.39 & $\mathrm{a}$ & 0.61 & a & 0.87 & a & 0.87 & a \\
\hline & & $\mathrm{CON}$ & 1.58 & $\mathrm{~b}$ & 1.80 & b & 2.07 & $\mathrm{~b}$ & 0.40 & $b$ & 0.67 & b & 0.71 & $\mathrm{~b}$ \\
\hline & $\mathrm{HF}$ & $\mathrm{WN}$ & 1.04 & $b$ & 1.07 & $\mathrm{~b}$ & 1.47 & $a b$ & 0.04 & $b$ & 0.07 & $b$ & 0.28 & $b$ \\
\hline & & BN35 & 1.06 & $\mathrm{~b}$ & 1.08 & $\mathrm{~b}$ & 1.63 & $\mathrm{a}$ & 0.04 & $\mathrm{~b}$ & 0.08 & $b$ & 0.44 & a \\
\hline & & BN50 & 1.02 & $b$ & 1.11 & $\mathrm{~b}$ & 1.36 & $\mathrm{~b}$ & 0.02 & $b$ & 0.10 & $b$ & 0.32 & $b$ \\
\hline & & PRO & 1.13 & a & 1.32 & a & 1.52 & $a b$ & 0.14 & a & 0.29 & a & 0.42 & a \\
\hline & & $\mathrm{CON}$ & 1.06 & $\mathrm{~b}$ & 1.24 & a & 1.40 & $a b$ & 0.06 & $\mathrm{~b}$ & 0.23 & a & 0.37 & a \\
\hline
\end{tabular}

Different letters next to values in each group indicate significant differences $(\alpha=0.05)$. ns $=$ not significant.

\section{Discussion}

\subsection{Microclimate and Sun Damage}

In the neotropical climatic conditions of our study, the increase and decrease in air temperature (AT) under WN and BN treatments, respectively, are in agreement with the values reported by other authors. The use of netting and its study differs as the climate of the region changes. In arid, semi-arid or Mediterranean climates (e.g., Washington State, main producing areas of Chile, Israel, South Africa), sunburn is a main objective, while in higher-latitude European conditions netting is mainly used as a protection against hail [11,21,37-39]. Climates with hot and humid summers, on the other hand, are not widely studied. The maximum AT exceeded $35^{\circ} \mathrm{C}$ in all treatments, with $\mathrm{WN}$ and Control reaching $43{ }^{\circ} \mathrm{C}$. These temperatures required homeostatic control mechanisms of cell metabolism, while also affecting fruit growth and pre- and postharvest quality [26,40,41]. Studies have shown that, under heat stress conditions, trees under photoselective nets had greater leaf-level photosynthetic light-use efficiency compared to the Control [19]. Photoinhibition at the peel chloroplasts and the consequent generation of oxygen free radicals seems to explain sunburn to a large extent [26]. As it has been reported, fruit temperature can be $17^{\circ} \mathrm{C}$ higher than air temperature [18]; therefore, damage could even occur at an AT above $29^{\circ} \mathrm{C}$. In the recorded period, the $\mathrm{WN}$ treatment presented $2 \%$ more days with AT $>29^{\circ} \mathrm{C}$ than the Control treatment, while the BN35 and BN50 treatments had 25 and $15 \%$ less days with that condition, respectively.

The effect of treatments on fruit surface temperature (FST) varied in relation to the observed effect on AT (Figures 3 and 4). All treatments under netting (WN, BN35 and BN50) reduced fruit temperature compared to treatments without netting (Control and PRO). The BN50 treatment had the highest homogeneity in FST, whereas the Control treatment had the lowest. The AT values recorded for BN35 and BN50 and their relationship with FST are in line with Gindaba and Wand [17], who report that the FST of apples under $20 \%$ black shade netting was between 5.4 and $9.7^{\circ} \mathrm{C}$ lower on days with AT between 34 and $37^{\circ} \mathrm{C}$, while the average decrease in FST with AT between 30 and $32{ }^{\circ} \mathrm{C}$ was $5.6^{\circ} \mathrm{C}$. 
Regarding the decrease in radiation in the netting treatments (Figure 5), the results are in accordance with those reported by Bastías and Corelli-Grappadelli [27], who state that black or white nets are generally neutral and reduce a similar radiation profile in the different wavelengths of the PAR range. The transmittance of the BN50 treatment in the 350 to $800 \mathrm{~nm}$ wavelength range showed a decrease in radiation values similar to those obtained by Dussi et al. [42] with a 55\% black net for PAR. The WN treatment presented transmittance values 20\% lower than those presented by Blanke [23] and similar to those presented by Bastías and Corelli-Grappadelli [27] for the PAR range. The behavior of $\mathrm{WN}$ in the 350 to $425 \mathrm{~nm}$ range differs from that recorded for BN50. The increases in transmittance observed in the values between 700 and $800 \mathrm{~nm}$ also differ from those recorded for BN50. The increase in infrared radiation $(>740 \mathrm{~nm})$ has a significant caloric contribution [43] and could be related to the increases in air temperature recorded in this treatment. Another element to consider in regard to the changes in radiation is the increase in diffuse radiation transmission, which can increase up to $170 \%$, thus improving light penetration both vertically and horizontally in the canopy [38].

The onset of symptoms in the trial (Figure 1) started at 6 WAFB, when fruits had an average size of $40.5 \mathrm{~mm}$, two weeks earlier than reported by Racsko and Schrader [18]. Between 10 and 15 WAFB, when the maximum rate of damage occurs in treatments without nets, fruit size was 42 to $62 \mathrm{~mm}$ (data not shown) (Figure 6). These data are in agreement with those reported by Racsko and Schrader [18], which shows that the occurrence of damage depends on the coupling of predisposing environmental conditions and a certain level of susceptibility with diameters of $45 \mathrm{~mm}$ at 7 to 8 WAFB. Although the most widely reported predisposing conditions are high temperatures and radiation [18], Severino et al. [10], for the same seasons and site, associate damage more with water availability than high temperatures.

Season has a significant effect on the incidence of sunburn, both in the assessments of marked fruits and in the harvest assessment (Figures 6-8). Our results show that two of the four studied seasons presented high percentages of sunburn (seasons 2 and 3), while seasons 1 and 4 presented less favorable climatic conditions for sun damage. These data confirm the high interannual variability in the region where the study was conducted [32]. The severity of damage also evidenced the variation among treatments, with the BN50 treatment showing the highest percentage of fruits without damage (without reaching statistical significance) and, among the damaged fruits, the highest percentage of Mild (Figure 8).

Sunburn protectant applications did not reduce neither the incidence (Figure 7) nor the severity of sunburn (Figure 8). The difficulties in achieving a permanent coverage with the product result in periods of time in which unacclimatized tissues, exposed to high FST and radiation conditions, suffer photooxidative stress that can lead to sun damage [44].

\subsection{Fruit Growth and Sprouting}

The effect of the treatments on fruit growth was of low magnitude and did not modify the commercial category (1.4 to $2.5 \mathrm{~mm}$ depending on the season). Similar effects are reported in apple crops under netting in a diverse range of climates [45] and in heat stress studies with temperatures of $29^{\circ} \mathrm{C}$ and higher when nets are applied since 4 WAFB (the period of treatment application in this trial) [41]. In turn, all sprouting variables evaluated in the netting and Control treatments (shoot length, percentage of reproductive shoots and percentage of spurs) showed differences related to season. The effect of treatments was only significant for the shoot length variable (Table 2). Apparently, the reductions recorded in the total incident radiation of the treatments under nets did not constitute a limiting factor for net assimilation. Studies conducted in Brazil, with irradiance values similar to those recorded in Uruguay [46], conclude that nets seem to promote the optimization of light interception and carbohydrate partitioning [31]. The average irradiance for the 2006-2015 period in the three months of highest incidence of sun damage [46] is 55\% higher in the location of our study and of the works of Bosco et al. [31], compared to the areas where 
adverse effects of the use of nets are recorded [23]. Changes in the incident light spectrum under netting were not significant enough to modify floral differentiation processes during the summer, nor did they affect bud break in the following season, in accordance with reports by Bastías and Corelli-Grappadelli [27].

\subsection{Post-Harvest}

Postharvest physiological disorders are determined by many factors. including maturity, nutrition, location of the fruit on the tree, and temperature to which it has been exposed [47]. The factors considered in our study (fruit condition when entering cold storage, field treatments, antiscaldant treatment and storage time) were significant in the model, both individually and for their interactions.

Both antiscaldant products significantly reduced scald damage, as reported in other studies [48]. Fruits entering cold storage without visible damage (HF) showed a lower range of damage than fruit with mild sun damage (Mild). The field treatments (Control, PRO, WN, BN35 and BN50) showed differences in scald and sunscald development for both classifications (HF and Mild) when entering cold storage (Figures 9 and 10).

In fruits with antiscaldant application (mainly expressing sunscald), the performance of treatments varied between seasons, with MN50 showing the best performance and PRO showing the worst (Table 3). Based on the assumption that the existing sun damage at harvest is neither reversible nor controllable, with the postharvest application of antiscaldant products $[7,18,49]$ the results would indicate a different level of damage at harvest and a different sensitivity to sunscald expression depending on the field treatments. This difference in sensitivity could be explained by the variation produced by the nets in the composition and the antioxidant capacity of the fruit's skin [50]. The biochemical modifications triggered in the exposed and acclimatized fruits to withstand the high solar irradiance and high temperatures in the field [7], as well as the photoinhibition in the chloroplasts of the peels and the subsequent generation of oxygen free radicals [26], could induce the disorder later on.

\section{Conclusions}

The incidence of sunburn was influenced by the season under neotropical conditions. The shade netting reduces the sunburn and sunscald without affecting the growth processes dependent on leaf net assimilation. Protectants, on the other hand, are not effective and can increase sunscald incidence on the fruit during storage. The fruit position within the tree and the initial condition were the main factors affecting sun damage. However, black netting or favorable season conditions can reduce (i.e., reverse) the earlier sunburn symptoms. This shows the need for more studies on the relation between microclimate and physiological conditions at different hierarchical levels (fruit tissue, organ, branch and tree).

Author Contributions: Conceptualization, V.S., M.A.-S., J.A.Y. and J.G.-T.; methodology, V.S., M.A.-S., E.F., J.A.Y. and J.G.-T.; formal analysis, V.S. and E.F.; writing-original draft preparation, V.S.; writingreview and editing, V.S., M.A.-S., S.D., E.F., J.A.Y. and J.G.-T.; visualization, V.S.; supervision, S.D., J.A.Y. and J.G.-T.; project administration, V.S. and M.A.-S.; funding acquisition, V.S., M.A.-S., J.A.Y. and J.G.-T. All authors have read and agreed to the published version of the manuscript.

Funding: Research funded by Agencia Nacional de Investigación e Innovación (RTS_X_2011_22868).

Institutional Review Board Statement: Not applicable.

Informed Consent Statement: Not applicable.

Acknowledgments: We thank Frutisur for their contribution to the funding of this work and for allowing us to use their crops, INIA (Instituto Nacional de Investigación Agropecuaria) and its members Alicia Feippe, Roberto Zoppolo and Danilo Cabrera for their participation in the research project, and CasaAmérica for their contribution to the materials used and their facilities. We also 
thank Marcia García, Sebastián Galiger and José Luis Álvarez for their contribution to the field and laboratory work.

Conflicts of Interest: The authors declare no conflict of interest.

\section{References}

1. Schrader, L.E.; Zhang, J.; Duplaga, W.K. Two Types of Sunburn in Apple Caused by High Fruit Surface (Peel) Temperature. Plant Health Prog. 2001, 2, 3. [CrossRef]

2. Yuri, J.A.; Torres, C.; Bastías, R.; Neira, A. Golpe de Sol En Manzanas. II. Factores Inductores y Respuestas Bioquímicas. Agro-Ciencia 2000, 16, 23-32.

3. Piskolczi, M.; Varga, C.; Racskó, J. The Meteorological Causes of Sunburn Injury on the Surface of Apple Fruit (Malus domestica Borkh.). J. Fruit Ornam. Plant Res. 2004, 12, 245-252.

4. Wünsche, J.N.; Greer, D.H.; Laing, W.A.; Palmer, J.W. Physiological and Biochemical Leaf and Tree Responses to Crop Load in Apple. Tree Physiol. 2005, 25, 1253-1263. [CrossRef] [PubMed]

5. Felicetti, D.A.; Schrader, L.E. Photooxidative Sunburn of Apples; Characterization of a Third Type of Apple Sunburn. Int. J. Fruit Sci. 2008, 8, 160-172. [CrossRef]

6. Yuri, J.A.; Neira, A.; Quilodran, A.; Razmilic, I.; Motomura, Y.; Torres, C.; Palomo, I. Sunburn on Apples Is Associated with Increases in Phenolic Compounds and Antioxidant Activity as a Function of the Cultivar and Areas of the Fruit. J. Food Agric. Environ. 2010, 8, 920-925.

7. Hernandez, O.; Torres, C.A.; Moya-León, M.A.; Opazo, M.C.; Razmilic, I. Roles of the Ascorbate-Glutathione Cycle, Pigments and Phenolics in Postharvest 'Sunscald' Development on 'Granny Smith' Apples (Malus domestica Borkh.). Postharvest Biol. Technol. 2014, 87, 79-87. [CrossRef]

8. Schrader, L.; Zhang, J.; Sun, J. Environmental Stresses That Cause Sunburn of Apple. Acta Hortic. 2003, 618, 397-405. [CrossRef]

9. Meheriuk, M.; Prange, R.K.; Lidster, P.D.; Porritt, S.W. Postharvest Disorders of Apples and Pears; Agriculture and Agri-Food: Ottawa, ON, Canada, 1994; ISBN 0662212371.

10. Severino, V.; Arias-Sibillotte, M.; Dogliotti, S.; Frins, E.; Gonzalez-Talice, J.; Yuri, J.A. Climatic and Physiological Parameters Related to the Progress and Prediction of Apple Sunburn Damage in a Neotropical Climate. Adv. Hortic. Sci. 2020, 34, 431-440. [CrossRef]

11. Szabó, A.; Tamás, J.; Nagy, A. The Influence of Hail Net on the Water Balance and Leaf Pigment Content of Apple Orchards. Sci. Hortic. 2021, 283, 110112. [CrossRef]

12. Torres, C.A.; León, L.; Sánchez-Contreras, J. Spectral Fingerprints during Sun Injury Development on the Tree in Granny Smith Apples: A Potential Non-Destructive Prediction Tool during the Growing Season. Sci. Hortic. 2016, 209, 165-172. [CrossRef]

13. Torres, C.A.; Sepúlveda, A.; Leon, L.; Yuri, J.A. Early Detection of Sun Injury on Apples (Malus domestica Borkh.) through the Use of Crop Water Stress Index and Chlorophyll Fluorescence. Sci. Hortic. 2016, 211, 336-342. [CrossRef]

14. Musacchi, S.; Serra, S. Apple Fruit Quality: Overview on Pre-Harvest Factors. Sci. Hortic. 2018, 234, 409-430. [CrossRef]

15. Parchomchuk, P.; Meheriuk, M. Orchard Cooling with Pulsed Overtree Irrigation to Prevent Solar Injury and Improve Fruit Quality of "Jonagold" Apples. HortScience 1996, 31, 802-804. [CrossRef]

16. Manja, K.; Aoun, M. The Use of Nets for Tree Fruit Crops and Their Impact on the Production: A Review. Sci. Hortic. 2019, 246, 110-122. [CrossRef]

17. Gindaba, J.; Wand, S.J.E. Comparative Effects of Evaporative Cooling, Kaolin Particle Film, and Shade Net on Sunburn and Fruit Quality in Apples. HortScience 2005, 40, 592-596. [CrossRef]

18. Racsko, J.; Schrader, L.E. Sunburn of Apple Fruit: Historical Background, Recent Advances and Future Perspectives. Crit. Rev. Plant Sci. 2012, 31, 455-504. [CrossRef]

19. Mupambi, G.; Musacchi, S.; Serra, S.; Kalcsits, L.A.; Layne, D.R.; Schmidt, T. Protective Netting Improves Leaf-Level Photosynthetic Light Use Efficiency in 'Honeycrisp' Apple under Heat Stress. HortScience 2018, 53, 1416-1422. [CrossRef]

20. Kalcsits, L.; Musacchi, S.; Layne, D.R.; Schmidt, T.; Mupambi, G.; Serra, S.; Mendoza, M.; Asteggiano, L. Above and Below-Ground Environmental Changes Associated with the Use of Photoselective Protective Netting to Reduce Sunburn in Apple. Agric. For. Meteorol. 2017, 237-238, 9-17. [CrossRef]

21. Tanny, J.; Cohen, S.; Grava, A.; Naor, A.; Lukyanov, V. The Effect of Shading Screens on Microclimate of Apple Orchards. Acta Hortic. 2009, 807, 103-108. [CrossRef]

22. McCaskill, M.R.; McClymont, L.; Goodwin, I.; Green, S.; Partington, D.L. How Hail Netting Reduces Apple Fruit Surface Temperature: A Microclimate and Modelling Study. Agric. For. Meteorol. 2016, 226-227, 148-160. [CrossRef]

23. Blanke, M.M. The Structure of Coloured Hail Nets Affects Light Transmission, Light Spectrum, Phytochrome and Apple Fruit Colouration. Acta Hortic. 2009, 817, 177-184. [CrossRef]

24. Solomakhin, A.; Blanke, M. The Microclimate under Coloured Hailnets Affects Leaf and Fruit Temperature, Leaf Anatomy, Vegetative and Reproductive Growth as Well as Fruit Colouration in Apple. Ann. Appl. Biol. 2010, 156, 121-136. [CrossRef]

25. Bastías, R.M.; Manfrini, L.; Corelli Grappadelli, L. Exploring the Potential Use of Photo-Selective Nets for Fruit Growth Regulation in Apple. Chil. J. Agric. Res. 2012, 72, 224-231. [CrossRef]

26. Naschitz, S.; Naor, A.; Sax, Y.; Shahak, Y.; Rabinowitch, H.D. Photo-Oxidative Sunscald of Apple: Effects of Temperature and Light on Fruit Peel Photoinhibition, Bleaching and Short-Term Tolerance Acquisition. Sci. Hortic. 2015, 197, 5-16. [CrossRef] 
27. Bastías, R.M.; Corelli-Grappadelli, L. Light Quality Management in Fruit Orchards: Physiological and Technological Aspects. Chil. J. Agric. Res. 2012, 72, 574-582. [CrossRef]

28. Bosco, L.C.; Bergamaschi, H.; Marodin, G.A.B. Solar Radiation Effects on Growth, Anatomy, and Physiology of Apple Trees in a Temperate Climate of Brazil. Int. J. Biometeorol. 2020, 64, 1969-1980. [CrossRef]

29. Schrader, L.E. Scientific Basis of a Unique Formulation for Reducing Sunburn of Fruits. HortScience 2011, 46, 6-11. [CrossRef]

30. Reig, G.; Donahue, D.J.; Jentsch, P. The Efficacy of Four Sunburn Mitigation Strategies and Their Effects on Yield, Fruit Quality, and Economic Performance of Honeycrisp Cv. Apples under Eastern New York (USA) Climatic Conditions. Int. J. Fruit Sci. 2020, 3, 541-561. [CrossRef]

31. Bosco, L.C.; Bergamaschi, H.; Cardoso, L.S.; Paula, V.A. de Microclimate Alterations Caused by Agricultural Hail Net Coverage and Effects on Apple Tree Yield in Subtropical Climate of Southern Brazil. Bragantia Camp. 2018, 77, 181-192. [CrossRef]

32. Bernardi, R.E.; Holmgren, M.; Arim, M.; Scheffer, M. Why Are Forests so Scarce in Subtropical South America? The Shaping Roles of Climate, Fire and Livestock. For. Ecol. Manag. 2016, 363, 212-217. [CrossRef]

33. Zibordi, M.; Domingos, S.; Grappadelli, L.C. Thinning Apples via Shading: An Appraisal under Field Conditions. J. Hortic. Sci. Biotechnol. 2009, 84, 138-144. [CrossRef]

34. Archbold, D.D.; Nosarzewski, M.; Wu, B.; Vuppalapati, P. Does Availability of Soluble Carbohydrate Reserves Determine Apple Fruit Set? Available online: https:/ / www.actahort.org/books/903/903_110.htm (accessed on 2 August 2021).

35. Corelli-Grappadelli, L.; Lakso, A.N. Fruit Development in Deciduous Tree Crops as Affected by Physiological Factors and Environmental Conditions. Available online: https://www.actahort.org/books/636/636_52.htm (accessed on 2 August 2021).

36. Torres, C.A.; Sepulveda, A.; Gonzalez-Talice, J.; Yuri, J.A.; Razmilic, I. Fruit Water Relations and Osmoregulation on Apples (Malus domestica Borkh.) with Different Sun Exposures and Sun-Injury Levels on the Tree. Sci. Hortic. 2013, 161, 143-152. [CrossRef]

37. Hunsche, M.; Blanke, M.M.; Noga, G. Does the Microclimate under Hail Nets Influence Micromorphological Characteristics of Apple Leaves and Cuticles? J. Plant Physiol. 2010, 167, 974-980. [CrossRef]

38. Mupambi, G.; Anthony, B.M.; Layne, D.R.; Musacchi, S.; Serra, S.; Schmidt, T.; Kalcsits, L.A. The Influence of Protective Netting on Tree Physiology and Fruit Quality of Apple: A Review. Sci. Hortic. 2018, 236, 60-72. [CrossRef]

39. Mupambi, G.; Schmeisser, M.; Dzikiti, S.; Reynolds, S.; Steyn, W.J. Ineffectiveness of Foliar S-ABA Application as an Apple Sunburn Suppressant Explained through Effects on Peel Biochemistry and Leaf Ecophysiology. Sci. Hortic. 2018, 232, $256-263$. [CrossRef]

40. Woolf, A.B.; Ferguson, I.B. Postharvest Responses to High Fruit Temperatures in the Field. Postharvest Biol. Technol. 2000, 21, 7-20. [CrossRef]

41. Flaishman, M.A.; Peles, Y.; Dahan, Y.; Milo-Cochavi, S.; Frieman, A.; Naor, A. Differential Response of Cell-Cycle and CellExpansion Regulators to Heat Stress in Apple (Malus domestica) Fruitlets. Plant Sci. 2015, 233, 82-94. [CrossRef] [PubMed]

42. Dussi, M.C.; Giardina, G.; Sosa, D.; González Junyent, R.; Zecca, A.; Reeb, P.R. Shade Nets Effect on Canopy Light Distribution and Quality of Fruit and Spur Leaf on Apple Cv. Fuji. Span. J. Agric. Res. 2005, 3, 253-260. [CrossRef]

43. Yuri, J.A. Daño Por Sol En Manzanas. Rev. Frutic. 2010, 8, 2-9.

44. Glenn, D.M.; Yuri, J.A. Photosynthetically Active Radiation $(\mathrm{PAR}) \times$ ultraviolet Radiation (UV) Interact to Initiate Solar Injury in Apple. Sci. Hortic. 2013, 162, 117-124. [CrossRef]

45. Bosančić, B.; Mićić, N.; Blanke, M.; Pecina, M. A Main Effects Meta Principal Components Analysis of Netting Effects on Fruit: Using Apple as a Model Crop. Plant Growth Regul. 2018, 86, 455-464. [CrossRef]

46. PVGIS-SARAH @ E European Communities, 2001-2017. Available online: https://ec.europa.eu/jrc/en/PVGIS/downloads/ SARAH (accessed on 2 August 2021).

47. Ferguson, I.; Volz, R.; Woolf, A. Preharvest Factors Affecting Physiological Disorders of Fruit. Postharvest Biol. Technol. 1999, 15, 255-262. [CrossRef]

48. Niu, J.P.; Hou, Z.; Ou, Z.; Hui, W. Comparative Study of Effects of Resveratrol, 1-MCP and DPA Treatments on Postharvest Quality and Superficial Scald of 'starkrimson' Apples. Sci. Hortic. 2018, 240, 516-521. [CrossRef]

49. Contreras, C.; Zoffoli, J.P.; Alcalde, J.A.; Ayala, M. Evolución Del Daño Por Insolación de Manzanas “Granny Smith” Durante El Almacenaje Refrigerado. Cienc. Investig. Agrar. 2008, 35, 147-157. [CrossRef]

50. Olivares-Soto, H.; Bastías, R.M.; Calderón-Orellana, A.; López, M.D. Sunburn Control by Nets Differentially Affects the Antioxidant Properties of Fruit Peel in 'Gala' and 'Fuji' Apples. Hortic. Environ. Biotechnol. 2020, 61, 241-254. [CrossRef] 